\title{
A MODEL For THE ENHANCEMENT OF AUTONOMY
}

(Um modelo para o desenvolvimento da autonomia)

\author{
Walkyria Magno e SiLVA \\ (Universidade Federal do Pará - UFPA)
}

\begin{abstract}
This article presents an innovative model for the enhancement of learner autonomy and shows some of its results and challenges. The model entails investigation of problematic areas of individual students' foreign language learning processes, identification of their privileged learning styles, use of technological tools to improve learning autonomy, development of a wider range of language learning strategies, and implementation of self-monitoring and self-evaluation routines. This model bas been applied for the last three years with undergraduate students, earning a B.A. in Modern Languages (English, French or German), who will become foreign language teachers in elementary and high schools in Brazil. Results are threefold: first, the model has proven its efficiency in providing scaffolding for students autonomous language learning; second, autonomy developing experiences lived by subjects who are studying to be teachers can be mirrowed in their future professional lives with their own students; and thirdly, data derived from the participants in the study can shed some light into the variety of ways people learn in the local context.
\end{abstract}

KEY-WORDS: Autonomy; Foreign Language Learning; Learning Styles; Learning Strategies.

RESUMO: Este artigo apresenta um modelo para o fomento da autonomia dos aprendentes, mostra alguns resultados alcançados na aplicação desse modelo e discute desafios ainda a serem enfrentados. O modelo comporta a investigação de áreas problemáticas do processo individual de aprendizagem de cada sujeito, a identificação de seus estilos preferenciais de aprender, o uso de ferramentas tecnológicas para melhorar a autonomia na aprendizagem, o desenvolvimento de um leque maior de estratégias de aprendizagem de linguas e a implementação de rotinas de auto-monitoramento e auto-avaliação. Este modelo tem sido aplicado nos últimos três anos com alunos de Letras cursando Licenciaturas em Alemão, Francês ou Inglês. Três ordens de resultados emergem dos dados da pesquisa: primeiramente, o modelo provou sua eficácia em prover um andaime para a aprendizagem autônoma de línguas dos alunos; em segundo lugar, as experiências de aprendizagem 
autônoma vividas pelos futuros professores de línguas poderão ser espelhadas em suas vidas profissionais futuras com seus próprios alunos; finalmente, os dados emanados dos participantes da pesquisa podem lançar uma luz sobre a variedade de maneiras pelas quais as pessoas aprendem no contexto local.

PaLAVRAs-CHAVE: Autonomia; Aprendizagem de Linguas Estrangeiras; Estilos de Aprendizagem; Estratégias de Aprendizagem.

\section{Introduction}

Since the seminal work of Holec (1981), autonomy has been extensively discussed in the field of foreign languages learning. As Little (1991) has stated, it has become a buzz-word in the area, yielding to a prolific academic production in these last two decades. It entails a transdisciplinary approach which draws knowledge from disciplines as Psychology, Sociology, Anthropology, among others.

Our interest in the theme came from observing diverse students' foreign language learning outcomes in the university we work. Only basic reading knowledge in a foreign language is required at the entrance examinations, but at the end of four years B.A. students leave the university with a license to teach the language they major in at elementary and secondary levels in Brazil. Some undergraduates have succeeded with the instruction provided at the university, while many others have not. We decided to conduct a small informal research in order to find out why this happened. Through the application of a questionnaire followed by an interview, we collected data of successful students who had learned English only at the University. This information demonstrated that the classes at the University were only the tip of the iceberg of the tremendous amount of other activities in the foreign language they got autonomously involved with. Corroborating many studies on foreign language learning narratives in Brazil (Evangelista 2005; Magno e Silva 2006; Paiva 2007; Sade 2005), we concluded that it was what students did outside the class, on their own, which made the difference in terms of attained proficiency at graduation. What happens is that proficient users of a foreign language usually reach beyond the classroom, searching for opportunities to expand their knowledge. This fact is widely present in the literature of the field, as in Benson (2001:65) who states that "it seems reasonable to conclude that most learners who 
achieve proficiency in a foreign language do so by employing a variety of modes of learning whithin which self-management of learning plays an important role". Passivity should, therefore, be left aside and learners should be encouraged to learn to make decisions about how to take over the role of managers of their own learning.

Action was undertaken and the research project Ways to Autonomy in Foreign Language Learning ${ }^{1}$ was created in order to provide B.A. in Modern Languages students at the Federal University of Pará, in Northern Brazil, with alternative possibilities of becoming proficient in the foreign language they intend to teach in the future. The university provided the coordinator of the project twenty research hours a week, and a group of three volunteers - all graduate students, advisees of the coordinator embraced the idea and worked voluntarily. The research project was designed and the team talked to the English professors of the Department asking them to refer students who were not doing so well in class to us. Teachers were receptive to this innovative idea once they understood that we would not teach their subject matter in our project, but help students to find out how they could learn better.

The aims of this action research project are to investigate the problematic areas of the students learning, help learners identify their priviledged learning styles, implement the use of technological tools to improve learning autonomy, help students develop a wider range of language learning strategies, and teach students how to conduct selfmonitoring and self-evaluation routines. Besides, as a research project, it was designed to provide some answers on how students learn in our context. Some of the results of research conducted within the project will be shown throughout this text.

In this article, the model of this project will be presented, some of its results will be demonstrated, and challenges it presently faces will be exposed. The model has proven to be effective in the enhancement of autonomous learning possibilities. After three years, it can offer a few sequences of procedures that have been worthwhile to experiment with and that have provided some answers to local problems.

1 More information on the project can be obtained at http://ufpa.br/cla/caale/ 


\section{Theoretical basis}

Theoretical basis for the project are autonomy in language learning (Holec 1981; Little 1991; Dickinson 1994; Benson and Voller 1997; Scharle and Szabó 2000; Benson 2001), learning styles (Felder and Soloman 1994; Nunan 1996 apud Gardner and Miller 1999; Reid 1998), learning strategies (Oxford 1990 and 1996), and the ideas of scaffolding in order to develop actions functionally important for the learner (Mercer 1994). We will briefly see how each of these theories illuminated our view of autonomy enhancing in the following sub-sections.

\subsection{Autonomy}

In this sub-section we will state some of the most important definitions of autonomy, priviledging the ones that have found an echo in the work developed at the project which is the focus of this article. We will also trace some paralels between these definitions and the way learners learn in our university context.

Holec's definition states that "autonomy is the capacity of taking charge of one's own learning” (1981:3). He complements the idea by saying that "taking charge of one's learning is to have, and to hold, the responsibility for all the decisions concerning all aspects of this learning" (1981:3). This definition must be understood in the context where adults, including senior citizens groups, were learning a foreign language. In that case, students themselves determined their objectives, defined the contents and pacing of learning, selected methods and techniques, monitored their own procedures, and, finally, evaluated their outcomes. The experience proved so satisfactory that many of Holec's ideas spread over Europe and became touchstones of the Council of Europe's effort for members of the European Community to teach and learn as many languages as they can. In the context of our university, the contents, the hours, and the curriculum are decided by the administration, based on guidelines lauched by the Federal Government, leaving little leeway for students' opinions. Neverthless, these guidelines offer only minimum elements, and it is up to teachers to offer other opportunities for decision making over the learning in each particular class. 
Little (1991) tended to follow a more psychological trend and priviledged the cognitive processes involved in autonomous study. $\mathrm{He}$ started by saying what autonomy is not, stating that autonomy is not selfinstruction or learning without a teacher, that it is not only a matter of how to organize the process of learning, that it cannot be "taught" to students, that it is not a single behavior, and that it is not a stable state to be achieved. Little defined autonomy as

a capacity for detachment, critical reflection, decision-making, and independent action. It pressuposes, but also entails, that the learner will develop a particular kind of psychological relation to the process and content of his learning. The capacity for autonomy will be displayed both in the way the learner learns and in the way he or she transfers what has been learned to wider contexts (1991:4).

In this definition we can perceive that the author brings to light the capacity of reflection, of internal awareness of how the learning process develops for each individual. We consider this a condition for change in attitude towards learning. Understanding how people learn and how cognitive capacities can be used in so many different ways can considerabely alter the result of learning. Another important point to state about Little's understanding of the matter is that, although he says that autonomy is not something that teachers do to learners, he recognizes the importante of the teacher's role in helping the learner become more autonomous.

Dickinson says that autonomy can be understood as "an attitude to learning rather than a methodology" (1994:2) or as a disposition to learn how to learn. This author emphasizes the role of the learner and the decisions he has to make in order to become more autonomous. Awareness of the difficulties, the steps that need to be undertaken, and valuable checklists for learners are his contributions to the area. Our students are generally very passive in the beginning of courses because they come from a teacherfronted model which is the rule in most schools where they have studied before. Therefore, they are not used to taking an active part in the class.

Benson and Voller (1997) edited a volume in which they discuss several types of definitions for autonomy and problematize the concept by saying that, once autonomy touches several different fields, it can serve different ideologies and present different discourses. Their book does not take sides and discusses the various views on autonomy in a very enlightening way. 
Scharle \& Szabó (2000) see autonomy as a process which goes through three phases: awareness, change of attitude, and transferring of roles. According to these authors, awareness is the first desirable state to be achieved: understanding that learning has to be done by students themselves. This might cause a change of attitude in students who then assume different roles in the learning process, thus, leaving behind passive behaviors. This, as we said before, is the main step to be taken in our context.

Benson states that "autonomy is a multidimensional capacity that will take different forms for different individuals, and even for the same individual in different contexts or at different times" (2001:47). This definition emphasizes that achieving autonomy is a very individualized path, which might or might not be desirable to the student himself. He might be autonomous in some situations, while in others he might feel it is more interesting for him not to be autonomous. In the same book, Benson develops the definition of autonomy associating it with the taking of control of a threfold process: control over learning management, control over cognitive processes, and control over learning contents.

Magno e Silva (2004) agrees with Benson's definition and states that the teacher's role must be redefined, aiming at the autonomous outcomes of the student. This possibility calls for a new positioning in classroom interaction between students and teacher. Therefore, teachers and students can proceed together, creating multiple opportunities for learning. The author calls this path a process, which can be created in every class and states that one step taken in any direction towards autonomy can result in being a catalyst to several others, creating the occasion for exponential growth in the learning process.

We understand autonomy as a multidimensional construct because it emcompasses many areas, like learning styles, learning strategies, motivation, affective factors, etc. When looking for solutions in one of these areas, one might find answers for others.

In order to explore these different forms that the capacity of autonomy assumes for each student is the reason why we decided to engage in the research project which we describe here. This valuing of autonomy is also a result of studies which place students as managers of their own progress and teachers as presenters of contents in different ways, not leaving aside 
the pecularities of each classroom. In these contexts, teachers act as providers of opportunities for students to excert control over their own learning experiences. Actually, this can be considered the goal of education in general, once learners won't be accompanied by teachers throughout their lives, formal education being a mere transitional stage in one's existence. Therefore, reaching progressively more autonomous capacity of studying should be the main objective for everyone.

\subsection{Learning styles}

In this sub-section we will present a working definition of learning styles and provide the basic elements for considering them as a valuable object of study for autonomy.

Learning styles can be understood as "internally based characteristics, often not perceived or consciously used by learners, for the intake and comprehension of new information" (Reid, 1998: ix). Psychologists began to study this aspect of learning not long ago and it soon became part of the foreign language classrooms studies. Tentative taxonomies of learning styles have failed to entail and explain the array of concepts in this fuzzy field, with authors providing numbers of styles which range from a few basic ones up to more than thirty different ones. Leaver (1997) provides a provisional division of learning styles in sensory modalities (auditory, visual or kinesthesic learners), cognitive styles (left or right brain functioning, reflexive or impulsive, ambiguity tolerant or intolerant, global or sequential, among others), personality types (introverted or extroverted), and environmental preferences (light or noise tolerant or dependent, food necessities etc).

In our context, verbal and linguistic styles are priviledged, giving students who are predominant in these styles a considerable advantage in classroom performance. In foreign language classes, students with introverted personality types, too reflexive, ambiguity intolerant, or even too kinesthesic suffer from classes which can be crashing with their preferred ways of learning. Knowing more about one's learning style can diminish the damages of inappropriate management of these personal characteristics.

In the case of the project we describe in this text, we assume that learning styles play an important role in the better learning of a foreign 
language and we have given learning styles tests for students who come to the project, as can be seen later. We also discuss with students the possibility of recognizing their teachers'styles and transforming information given in their teachers' style into their own learning styles, thus avoiding what Leaver calls "styles wars in the classroom".

\subsection{Learning strategies}

In this sub-section we briefly present some of the studies about learning strategies as one of the fundamental stones of the project because we understand that actions performed by students can be as diverse as there are students. Many authors have spent some time and effort studying learning strategies (O'Malley and Chamot 1990; Oxford 1990; and Cohen 1998; just to mention a few), making the decade of the nineties of the last century the decade of learning strategies. Although learner training, a concept which underlies the one of learning strategies itself, has subdued because of the heavy behavioristic load of the word "training", work on reflective strategy use is still welcome in language classrooms, naming it "learner development". Only recently some foreign language syllabi have incorporated the explicit mention to language strategies as a way of learning better. Moreover, previously conducted studies have observed that more proficient adult students use a wider variety of strategies to learn a new language (Magno e Silva 2006).

According to Oxford, "learning strategies are specific actions taken by the learner to make learning easier, faster, more enjoyable, more selfdirected, more effective and more transferrable to new situations" (1990:8). Taking a more strategic stance towards learning helps students to reflect on their better way of learning, to act upon needs and wants they identified, and to make better use of their time. As a result of using appropriate learning strategies allied to preferred learning styles, the learning process becomes more interesting and successful in the eyes of the learner himself.

Oxford produced a classification of strategies, dividing them into direct and indirect strategies and then again in sub-groups of three in each main division. The direct strategies deal with language itself and are subdivided into cognitive, memory, and compensation strategies. The indirect group deals with the process of language learning and is subdivided into 
metacognitive, affective, and social strategies. This classification gave way to the creation of the Strategy Inventory of Language Learning (SILL) which we use in the project. The advantage of Oxford's SILL is that it is used worldwide and has proved to be a reliable instrument of investigation (Oxford 1996). The author herself is very clear about stating that the list of fifty actions described in the inventory is not exhaustive. The actions represent just what can be done by learners in the six groups of strategies; however, other strategies may be included. The main value of the inventory, in our opinion, is to show students exemplars of ways to learn that they sometimes hadn't even imagined before. Reflecting about one's results and comparing them with other students' results make students more aware of the myriad of factors involving language learning.

\subsection{Scaffolding}

As an echo to Little, Scharle and Szabó, and Benson, mentioned above, we also believe that scaffolding students to become more autonomous is perhaps the teacher's most important role. The work conducted at the project Ways to Autonomy in Foreign Languages Learning involves the idea of scaffolding understood as

... help which will enable a learner to accomplish a task which they would not have been quite able to manage on their own, and it is help which is intended to bring the learner closer to a state of competence which will enable them eventually to complete such a task on their own. (Mercer 1994: 97).

When tutors at the program guide students through the identification of their problematic areas in learning, help them recognize their learning styles, assess their use of learning strategies and guide them to their expansion, and, finally, help them monitor their own learning and assess their success, they are performing scaffolded actions at their best. Through this aid, the main goal of the project will be achieved: to have students perform alone varied actions that will make them learn more and better, in an exponential way (Magno e Silva 2004).

Scaffolding is provided throughout the actions undertaken at the project, always situating students difficulties at their real level, without oversimplifying them. This means that problems students might present 
are confronted as normal intercourses within the language learning process which is represented by a continuum that goes from their native language to desirable language proficiency in the target language. Tutors usually tell students that they themselves have encountered difficulties in their own language learning trajectories and found individual ways to overcome them.

\section{The context}

In this section we will describe the context in which this model was originated, the reasons for our concern and the public it is aimed at.

The Autonomous Learning Support Base (ALSB) was created within the project as a safe environment for the investigation of problem areas in each student's learning process. Presently it involves English, French, German, and Spanish students, student tutors, and teachers. In this space individual solutions are proposed which involve autonomous study actions for each student. Tutors accompany students in these actions, aiming at their gradual independence.

Reasons for setting up of the base were to break cultural paradigms of passivity which were common among these students, who lacked study skills, who presented low self-esteem, and who needed to reach out for other learning opportunities outside their classrooms. Although this model has been created to be applied in this context, it does not mean that it cannot be adapted to other types of institutions and audiences.

The project is based on three pilars: intrinsic motivation, scaffolding, and research and teaching.

Firstly, we believe that motivation to attend the project has to be intrinsic to the student. For this reason, students' actions in the project have no official contact with the disciplines or the students' grade records; thus, attending the ALSB does not provide any extra credit to them. Students come to the project when directed by their teachers, but they do so voluntarily and come back if and as many times as they wish. Better results in the classroom will come as a consequence of the work conducted at the ALSB.

Secondly, scaffolding is provided through the work of the research team at the ALSB. The original staff that started the project has evolved to 
presently house six members of the faculty: one general coordinator - who is also responsible for English, one responsible for each of the other foreign languages, one responsible for Computer Assisted Language Learning (CALL) activities for all languages and one responsible for self-monitoring and self-assessment procedures. There are between 5 and 12 tutors working with the students; the number varying according to their time availability each semester. These tutors are undergraduate or graduate students who receive an introduction to research methodology. They are fluent in the language they study and, therefore, are able to help other learners. They are trained by the teachers who work at the project or by the general coordinator. They are mostly volunteers with the exception of two English students who had partial funding through a university undergraduate research program ${ }^{2}$. In this case, they dedicate a weekly work load of 20 hours to the project. The students who benefit from the program, and who are scaffolded in their learning process, are the ones who are failing to follow the mainstream foreign language classroom. They come to BA3 as a paralel activity besides the regular instruction they receive in class. They remain at the project as long as they feel they need in order to go back and fit in the regular learning environment.

Finally, the project involves research, mainly in the area of learning how to learn, once tutors in the project are undergraduate students, graduate students and professors. Masters dissertations and undergraduate term papers have been developed using the data from the project. Piedade (2004) has proven the importance of collaborative work in the development of autonomous learning. Ana Carolina Costa (2005) compared the use of direct and indirect strategies (Oxford, 1990) of students in the project. Moreira (2007) studied the appropriation of autonomous learning techniques for vocabulary improvement. Nascimento (2007) conducted a longitudinal qualitative study analysing the path of four students in the project in their trajectory of becoming more autonomous. The team involved in the research project has not missed opportunities of sharing the knowledge derived from their findings in local conferences and workshops. These local presentations have also helped other teachers in the Foreign Languages Department understand and redirect their roles as teachers promoters of autonomous learning.

2 PIBIC - UFPA in the years of 2005-2006 and 2007-2008. 


\section{The model}

In this section we will describe the procedures taken at the ALSB with the objective of presenting it as a model to be applied in other contexts as well as submiting it to scrutinization by other researchers who can contribute for its improvement. The work in the project can be divided in three phases: investigation of problematic areas, the work in progress, and the establishment of the autonomization process.

\subsection{The investigation phase}

Every semester, after the first two weeks of classes, in which teachers get to know their students better, every faculty member who has a foreign language class, receives a form to send students to ALSB. They fill out the form with the names and their perceptions of students' difficulties and return it to the ALSB coordination. At the same time they invite these students to come to the project, where they will be offered help on how to study the foreign language more appropriately. Teachers had an overall positive attitude towards the project, once it would supply their students with extra help and motivational strenght to pursue better results in the regular classroom. When proficiency of students started to improve, some of these teachers demonstrated interest in participating in the group and conducting their own research as well.

Students voluntarily come to the ALSB in the days and hours in which there are tutors to help them in their languages. The schedule of the tutors is on the door of the room which houses the ALSB.

Upon arrival at the project, students are informed that they will not receive private language classes, but that they will explore some of their difficulties and search for alternative ways to autonomously overcome them. Through this tutoring, they become aware that they will have to take an active role in the process and that it is important to perform daily actions to improve their learning process. If they agree to stay in the project, they receive a number which is different from their registration number at the university. This number will serve for the project documentation and will keep the information separate from university records. By doing so, we believe we are reinforcing intrinsic motivation, once students will not come to the ALSB to get extra credit, but to learn better for its own sake. 
The first thing students do at the project is to fill out an enrollment protocol in which they identify their perceptions about their strong and weak areas of the foreign language learning. They also include information on their available hours to come to the project and other basic information.

Next, students take the Strategy Inventory of Language Learning (SILL), version for speakers of other languages learning English (Oxford, 1990). This test has been translated for students who do not speak English well enough to be able to understand it in English and for the ones who study other languges (French, German or Spanish).

The investigation phase also comprises one or two tests on learning styles. Among the array of tests available, we chose three to offer to students: the first one, adapted from Nunan (1996 apud Gardner and Miller 1999:159-160); the other one by Felder and Soloman (1994), which is available on line; and the Style Analysis Survey (Oxford apud Reid 1998:179-186). All the tests have been translated into Portuguese and are used in paper form or on-line, depending on the students preference. As for the learning styles test, as there are three of them, students choose which one they wish to take or they may want to take more than one and in different times throughout their work in the project.

Students are also encouraged to write their language learning narrative, which will help them reflect on the process of learning a language and what they do in order to learn it. These narratives have proven to be a valuable instrument to both the awareness of students' way of learning and what they do (or not do) in order to learn it, and also for research purposes in the project. Other studies have mentioned the importance of reflecting and writing one's own perceptions about his learning career (Benson and Nunan 2005; Paiva 2007, among others). The narratives written by the students at the project are filed with their own materials and a copy is kept in the project's general file, with or without identification, according to students' wishes. All students have access to other students' narratives as well as to tutors' narratives. By reading them, students can perceive that learning a foreign language is not always a smooth path and people overcome troubles in several different ways, mobilizing diverse potentialities, according to their individual preferences or opportunities. By reading other learners stories they see they are not alone in the task of learning a language and feel supported, thus lowering their level of anxiety. 
Besides, reading the innovative solutions other people have found to overcome their own difficulties provide more ideas to apply or adapt to their own situation.

Some students do all these steps on the same day, others take weeks to complete all the required protocols. The time students take to complete all the steps is also an important element that is being observed by the tutors because it carries a great deal of information on the students' way of doing things, as we will see in the results section later. With all these instruments results put together, the members of the research team feel they have a reasonably complete picture of the learner's process of learning a foreign language. Tutors then negotiate with learners an action plan, taking into account the information they have and the goals students want to reach. The awareness of the distance between where students are and where they aim to get, seen under the perspective of possibilities of growth and learning, acts as an important motivational tool. Tutors stand by learners and provoke them to become more autonomous.

\subsection{The work in progress}

After the investigation phase, the tutor analyses the material and talks to the student, trying to make him aware of his weaker points in the learning process.

In order to start the work, tutor and student look at the SILL results and pick up the two groups of strategies which had the lowest scores. Among the strategies of these two groups, the student chooses one or two which he will intensively work. These strategies will be implemented in the study program of the student, always taking into account his preferred learning styles. Based on these elements, students and tutors agree on signing a learning contract (Genesee and Upshur 1996; Malcom and Rindfleisch 2003). Some students who have a low score in the group of strategies called "organizing and managing your learning" need to be helped in designing a weekly study schedule to provide enough time for the study actions they need to do. This kind of students are usually very disorganized and they generally are not conscious that learning a language is a long-term process and learners have to provide the necessary time for specific work. 
Students are also invited to go to the computer lab where paralel actions of study skills using computers and the Internet are conducted. The professor who tutors students at the lab has extended experience in scaffolding students in using the computer for autonomous study (Costa, C.B.R., 2005). A choice of free sites for practicing various skills is also available for each language at the project homepage.

After these procedures, students monitor their learning process and adjust their actions accordingly. They have the feeling that learning is a continuous action and that "autonomy implies not only that learners attempt to take control of their learning from time to time, but that they possess the capacity to do so systematically" (Benson 2001:75). They also realize that learning better in one area may yield to better learning in other areas, which pictures the idea of Magno e Silva's exponential learning, expressed above.

The next step is for the student to decide when he will come back to the ALSB to talk to the tutors about the actions he has performed, about what he has accomplished and to express his ideas about if he is now in a better track or if he wishes to change any action in his contract, thus renegotiating it. This return to the project happens usually every week or every fifteen days. An important study conducted within the project about the role of monitoring and assessing one's own learning has shown that self assessment is essential to the development of autonomous learning because it helps to establish goals, perceive strong and weak areas, selfcorrect errors, and be aware of the responsibility for one's own learning (Porto 2005). The same author also mentions that by evaluating their own work, students feel more motivated and their self-esteem is enhanced. Selfesteem seems to be an area that needs work, as it was seen by Niwa and Santos (2005). According to these authors, students rarely employ affective strategies and this area needs affirmative scaffolding at the ALSB.

All actions undertaken by each individual student are recorded in a $\log$, kept in each student's file, which remains at the project headquarters. The tests, the assignments, the learning contract, the narrative are all collected in this file as well. After some time, going through the file gives the student a sense of accomplishment when he compares what he found difficult before and what he is presently doing with little or no effort. The filed data will also serve for research purposes. 


\subsection{Establishment of the autonomization process}

When students feel that they are able to continue performing the actions necessary to learn in a continuous and effective way, they report to the tutors and then they do not have to come to the the ALSB anymore. They are asked to write a final narrative to leave for the project records and continue attending the regular classes, now with the study skills they have learned. Some of the results achieved can be seen in the next section.

\section{Some results}

In this section we will describe some of the qualitative results obtained in the first three years of the project.

In the long term research we conducted, we identified the first and the second student's visit as the most important ones. If they understand what the project is all about and if they undergo a considerable part of the investigation process, it is very likely that they will keep coming to all the phases and perform the work previewed for them. On the other hand, there is a large amount of students who come only once or twice and for these the ALSB does no good. Anchored in these results, tutors are trained to be specially attentive in the first visits and to try their best when explaining the goals of the project and making it clear that, if students hold on and show some degree of endurance, results will start to appear very soon.

In the daily work with students, there are moments in which the researcher actually sees the beginning of the implementation of new study skills. From this moment on, the student becomes aware that he himself is able to use strategies that he didn't use before. Some of these magic moments are described below.

One student included in her contract that she needed to read stories in order to expand vocabulary and then she would retell the story to the tutor to practice her speaking skills. One day in December 2004, she was retelling the tutor the first five chapters of The Secret Garden. Three other students were in the same room doing other activities. Little by little these other students finished doing their own activities and started to pay attention to the story. By the way, it is important to state that the story 
teller had a very low score in managing emotions while speaking English because she was usually ashamed of speaking the target language. When she noticed that everyone in the room was listening to her, she hesitated and wanted to stop, but, with the encouragement of the tutor, she went on. Right then, she implemented the strategy of trying to speak the foreign language even when afraid of making mistakes or being criticized. She finished her story and received a round of aplause from her small audience.

As we have previously mentioned, the time students take to complete the investigation phase varies. Some do it very quickly, others take a long time and even use the investigation process itself as an enhancer of their learning process. One very careful student took three half hour sessions in different days to complete only the SILL. She reported that her behavior had changed since the beginning of the completion of the inventory, once she had started using the strategies mentioned in the test before even finishing to respond to it.

One student was studying the time adverbs "once", "twice"," three times", etc. and talking to one of the tutors she said "twice times". The tutor just looked at the student and she promptly reformulated it into only "twice" and then said "Ok, ok, I know, twice is already two times; it is redundant just like somebody people, isn't it?" This student transferred what she learned in one context to another one and related something she just learned to something she already knew. Once these processes are established, they can appropriately inform language learning in many occasions. So, being aware that one is capable of engaging in these processes will certainly enhance learning.

Another student volunteered to conduct a conversation group during vacations. When classes resumed, she presented a report in which she said that "talking in the group was a rewarding experience because there was interaction within the group and the activities they performed helped to develop conversational abilities of the participants".

While talking about these experiences with students, tutors help them become aware that the more they try to use the foreign language, the more they will learn. The incorporation of indirect strategies, mainly the metacognitive ones, have a major role in learning to learn a foreign language (Costa, A.C., 2005; Magno e Silva 2006). 
The better performance of students who attend the ALSB can also be seen in reports of other sources. After two years of the implementation of the project, we conducted a major evaluation of its effectiveness by distributing different questionnaires to the various people involved in the process: classroom teachers, project tutors, and students who attended the ALSB. Questionnaires were prepared and answered in Portuguese and, for the purposes of this paper, we conducted a free translation of the answers. Below are some excerpts derived from these questionnaires' answers.

Classroom teachers who answered their questionnaire mentioned that

(1) Some students change little. Most of them, however, show a great difference in the classroom, concerning participation and oral skills performance. They are more confident.

(2) I noticed some improvement. Students become more demanding. They ask for immediate feedback; for example, the ones that do not go to the ALSB do not have this kind of behavior.

Comments (1) and (2) show the degree of awareness reached by these two teachers' students and their critical skills to try to understand why they made mistakes and what kind of mistakes they were making in order to take immediate action to minimize them. Most of the faculty supported their students coming to the project and felt enthusiastic about the positive results shown by most of them.

Tutor's testimonials assure us that scaffolding is happening not only in the axis tutor towards ALSB students, as in excerpt (3), but also in the axis which comprises more experienced researchers towards tutors, as in excerpts (4) to (7). They said that

(3) Students feel supported. They begin to reflect on their problems and the ways they can overcome them.

(4) I learned how to be more organized to record data for future research.

(5) My theoretical advancement is important, which will be very useful when I become a teacher.

(6) We have access to excellent materials and a nice environment, which is a perfect match for enhancing a colegial athmosphere.

(7) I presented my first workshop alone; exactly the way I had dreamt doing.

The students questionnaires were the longest ones and showed us that the work has been worthwhile. Students reported simple actions like the ones of organizing their study time, as we can see in (8) below:

(8) I learned to organize my schedule in order to have time to study English. 
They expressed a very conscious way of learning and an awareness about what learning a foreign language is, as we can see in excerpts (9) to (13) below:

(9) It was at the ALSB that I found out I was capable of learning a foreign language.

(10) I learned that there is more than one way of learning a foreign language and that we cannot keep blaming others for our difficulties.

(11) The ALSB made me get out of being naive about language learning and become more critical about it. From suffering to hope of learning English.

(12) One of the best things at the ASLB was the monitoring system. I can say I was rescued in my learning.

(13) I feel very happy when my classmates acknowledge my improvement.

We can attest the importance of future language teachers undergoing these experiences, as stated in (10) when this student is aware that his future students will also demonstrate different ways of learning and that he, as a teacher, knows that he will need to teach in diverse ways in order to reach out to a greater number of students. In excerpt (13) the student rejoices for being able to present a high degree of achievement before his classmates. This will certainly create a more friendly athmosphere for learning.

The excerpts below show how one must invest time and effort to promote the loss of fear which paralyses any autonomous action.

(14) I noticed that I learn more when I take risks than when I keep quiet or speak only when I'm sure about the language to use.

(15) ALSB prompted me to dare and this makes me accept my challenges and feel encouraged to go beyond my limits.

(16) I learned that I cannot feel intimidated by my difficulties and that I am able to overcome the obstacles that are or will be on my way.

In the excerpts above we can see that affective strategies were demonstrated and scaffolding was proved to be of fundamental importance in a work of this kind. In excerpt (16) we can see the proof that this student has become autonomous once, by looking at past successful experiences, she foresees her ability of overcoming future difficulties.

Finally, some students' selections corroborate the idea previously mentioned that being autonomous does not mean learning only without a 
teacher. Actually the teacher is even more needed to provide guidance and choices to the student, as we can see in excerpt (17) below:

(17) I read more in English, I speak more, I write more. I cannot say I don't need a teacher anymore. On the contrary, I need a teacher, but now I don't depend on the teacher exclusively. I noticed that I need all the possible ways to learn a foreign language: the teacher, books, magazines, films, a coleague who knows more than I do etc...

This student has shown he has achieved control over learning by choosing other sources of input which are not dependent on the teacher alone.

We believe that the informed action of tutors, who stand by students' side, listen to them, and help them reflect on their peculiar trajectories as language learners is the strong aspect of the model. Showing students new possibilities of learning and letting them choose their own way is a safe path to enhance autonomy.

Students' motivation to learn the foreign language they will teach in the future is enhanced by reasonable goals set for themselves and the scaffolding provided by tutors. In addition, research conducted in the project has proven that individual paths are the rule in language learning, but the sense of achievement when little successes start to appear seems to be a pattern. This sense of achievement reinforces the willingness to improve even more.

Some shortcomings also appear in the model. As for the students aimed by the project we hold strong concern for the ones who do not come and for the ones who come only once or twice and, therefore, do not even complete the investigation process. For the latter we are investing time and skills in training tutors to receive these students accordingly in order to keep them at the ALSB long enough for them to start having the first results. As for the ones who, even when directed to the ALSB by their teachers, do not come at all, we have to respect their choice of not wanting to become autonomous students. However, in this case, we are surprised because once they are enrolled in a language teaching major, we do not understand their position of refusing to learn the language they will be licensed to teach in the future. Further investigation needs to be conducted with these students in order to find out the reasons there might be that 
can explain this fact. Some work has been done with failing students of language courses (Steffen 2006), but what makes the situation in our university peculiar is that they will be foreign language teachers in the future and, therefore, need to know the language in order to succeed in their professional lives.

Another challenge is to design a better materials arrangement, which has been tried out in the last months. We decided to organize materials and to guide students'contracts under a genre based approach. The experiments already conducted have proven to be successful (Castro and Magno e Silva 2007). More work on the theme needs to be conducted, though.

The data collected in the project has yielded papers, dissertations, and conference presentations, but more has to be done. Some research results have already come to light (Castro \& Magno e Silva 2007; Costa, A.C., 2005; Magno e Silva 2004, 2006; Moreira 2007; Nascimento 2007; Niwa \& Santos 2005; Piedade 2004; Porto 2005). In the first semester of 2007, the project hosted monthly coloquia, on themes like affect in language learning, awareness and self-monitoring strategies, narrative studies, and the teachability of autonomy, all of which gathered some public and proved to be important for studies development. Whenever there is an opportunity for presenting workshops, giving lectures or other academic activities, members of the group have taken a stand. We have also tried to extensively participate in local, national and international events, failing to attend only because of time or funding constraints.

\section{Conclusion}

The study has concluded that areas like self-awareness of what learning a foreign language is and knowledge about different ways of learning a language are of fundamental importance for students' success. Empowering students in order for them to decide how and which way to go is the key to having better language learners.

The project will complete four years in March 2008, when its planned duration will come to an end. With the partial results we are able to show at the moment, we expect that most students will present proficiency level 
and will be able to successfully excert their functions as teachers in elementary and secondary schools in our state. Some will proceed to graduate studies in Applied Linguistics, perhaps motivated by what they learned about learning in the project.

Our results also show that an ALSB like the one described here can be extremely helpful to students and teachers alike. Therefore, we plan to create resource center that will help not only the students who present difficulties for learning, but also all students who can develop their endless search for knowledge.

As for space and the funding, we will insist on negotiating these needs with the university administration. However, what is lacking in the physical side is compensated by the rising number and quality of volunteer tutors, which is the proof that it is possible to enhance proficiency of future language teachers, so necessary in our community.

Recebido em maio de 2008 Aprovado em dezembo de 2008 E-mail:wmagno@ufpa.br

\section{REFERENCES}

Benson, P. 2001. Teaching and Researching Autonomy in Language Learning. Harlow: Longman.

Benson, P. \& Voller, P. 1997. Autonomy E Independence in Language Learning. Harlow: Longman.

Castro, A.S. \& Magno e Silva, W. 2007. Genres promoting students autonomization. In: IV Simpósio Internacional de Estudos de Gêneros Textuais. Tubarão. Programa Tubarão, SC: UNISUL, p. 352-353.

Cohen, A. 1998. Strategies in Learning and Using a Second Language. Harlow: Longman.

Costa, C.B.R. 2005. Desenvolvimento de Comportamentos e Atitudes Autônomas com o Uso do Computador: Um Estudo de Caso. 98f. Dissertação (Mestrado em Lingüística) Curso de Mestrado em Lingüística, Universidade Federal do Pará, Belém. 
CosTA, A.C. 2005. Language learning strategies: a way to autonomy. $51 \mathrm{f}$. Trabalho de Conclusão de Curso (Licenciatura em Letras) UFPA, Belém. Dickinson, L. 1994. Learner autonomy: what, why and how? In: Leffa, V. (Ed). Autonomy in Language Learning. Porto Alegre: UFRS, p.2-12.

Evangelista, H.A. 2005. Compreendendo o processo de ensino/ aprendizagem de línguas estrangeiras através da utilização de históricos de aprendizagem. In: $15^{\circ}$. INPLA. São Paulo: PUC-SP.

Felder, R. \& Soloman, B. http://www.engr.ncsu.edu/learningstyles/ ilsweb.html. Acess on Sept. 9, 2007.

Gardner, D. \& Miller, L. 1999. Establishing Self-Access. From theory to practice. Cambridge: Cambridge U. Press.

Genesee, F. \& Upshur, J. 1996. Classroom-based Evaluation in Second Language Education. Cambridge: Cambridge.

Holec, H. 1981. Autonomy in Foreign Language Learning. Oxford: Pergamon. Leaver, B.L. 1997. Teaching the whole class. Thousand Oaks: Corwin Press Inc.

Little, D. 1991. Autonomy: Definitions, Issues and Problems. Dublin: Authentik.

Magno e Silva, W. 2004. Autonomia e saber exponencial no ensino e aprendizagem de línguas. In: VIII Jornada de Estudos Lingüísticos e Literários. Belém. Program ... Belém: UFPA, p. 101-102.

. 2006. Estratégias de Aprendizagem de Línguas Estrangeiras Um Caminho em Direção à Autonomia. Revista Intercâmbio, vol. XV. São Paulo: LAEL/PUC-SP.

Malcom, D. \& RindfleisCh, W. 2003. Individualizing Learning through Self-Directed Projects. English Teaching Forum. Washington, v.41, no. 3, p.10-15, Jul.

Mercer, N. 1994. Neo-Vigotskyan Theory and Classroom Education. In: Stierer, B. \& Maybin, J. (Ed.). Language, Literacy and Learning in Educational Practice. Clevedon, Avon: Multilingual Matters Ltda, p. 92-110.

MoreirA, G.C.P. 2007. Autonomous Vocabulary Learning. 34f. Trabalho de Conclusão de Curso (Licenciatura em Letras) UFPA, Belém.

Nascimento, C.A.M. 2007. Investigando a Influência das Crenças de Alunos do Curso de Letras da Universidade Federal do Pará sobre sua Prontidão para a Aprendizagem Autônoma de Inglês: um estudo de caso. $93 \mathrm{f}$. Dissertação (Mestrado em Lingüística) Curso de Mestrado em Lingüística, Universidade Federal do Pará, Belém. 
Niwa, S.L. \& SANTOS, D.L. 2005. Estratégias afetivas e ensino-aprendizagem de línguas: a experiência da BA3. In: IX Jornada de Estudos Lingüísticos e Literários. Belém. Proceedings ... Belém: UFPA, 20052007. p. 45-48.

O’Malley, M. \& Снамот, A. 1990. Learning strategies in second language acquisition. New York: Cambridge U. Press.

OXFORD, Rebeca. 1990. Language learning strategies: What every teacher should know. Boston: Heinle \& Heinle.

PaIVA, V.L.M.O. http://www.veramenezes.com/narrativas.htm Acess on Sept. 9, 2007.

Piedade, R.G. 2004. All for one and one for all: an attempt to simultaneously apply autonomous learning and cooperative learning in EFL classrooms. $34 \mathrm{f}$. Trabalho de Conclusão de Curso (Licenciatura em Letras) UFPA, Belém. PORTO, C.V. 2005. O papel da avaliação no aprendizado autônomo. In: IX Jornada de Estudos Lingüísticos Literários. Belém. Proceedings ... Belém: UFPA, 2005-2007. p. 40-44.

REID, J. 1998. Understanding Learning Styles in the Second Language Classroom. New York: Prentice Hall Regents.

SADE, L.A. 2005. Identidade e aquisiz̧ão em narrativas de falantes e aprendizes de línguas estrangeiras. In: $15^{\circ}$. INPLA, PUC, São Paulo.

Scharle, Á. \& Szabó, A. 2000. Learner Autonomy: a guide to developing learner responsibility. Cambridge: Cambridge.

StefFen, A.H. 2006. O outro lado da alegria de iniciar o estudo de uma nova língua: dados da desistência entre aprendizes. Horizontes de Linguística Aplicada. 5:2. Brasília: Dec. p. 40-57. 